\title{
RECOMMENDATION TO STARVATION
}

\author{
Sylvia Townsend Warner
}

Supper for five persons; Fried eggs: 4 eggs, 4 pieces of toast. Another such supper; Cheese savoury: 2 slices of bread toasted, 4-6 ozs. of grated cheese. A dinner for five persons: Cornish pie: few pieces of cold meat - about 2-4 ozs., $1 \mathrm{lb}$ potatoes, 2 onions, $1 / 2 \mathrm{lb}$ flour, $4 \mathrm{ozs}$. lard. Another; Sausages in batter: $1 / 2 \mathrm{lb}$ sausages. Skin the sausages and roll them in twelve portions.

These five persons are not, as one might suppose, maniacs thinning. They are a family on the dole, living within the scale prescribed by the Nutrition Committee of the British Medical Association (1933 Report), 'if health and working capacity are to be adequately maintained'.

The recipes are given in a booklet called 'Family Meals and Catering' issued by the B.M.A. with the assistance of the National Training College of Domestic Science, London. The original report dealt in such terms as calories and carbohydrates. The cooking book (based on diet 16 of that Report, the diet which allows $1 / 2 \mathrm{lb}$ of butter a week among five) is designed to show how it works out in real life.

Maybe it would be better to say 'works out in slow death'. One-tenth of a pound of sausages, one-fifth of 2-4 
ozs of cold meat - these are the dinners to keep adults in 'health or working capacity', or to nourish children.

In addition to its recipes 'Family Meals and catering' gives three weekly shopping lists. 'Butter, $1 / 2 \mathrm{lb}$; margarine $1 / 2 \mathrm{lb}$; eggs, 3 ; tomatoes, $1 / 4 \mathrm{lb}$; greens, 2 pennyworth; lettuce, one pennyworth.' These proportions are not a week's supply for one person, as a normal housekeeper might assume. They are a week's marketing for five.

'Family Meals and Catering' - how smug this title begins to sound! - is ornamented with three specious coloured plates, each showing a week's supply of food. More to the point is the photograph on the cover. Here is the food again, cooked according to the recipes by the Students of the National Training College of Domestic Science. The dishes are set out on a staging covered with a fair white cloth, and the students, covered with fair white overalls, are standing by. In only one instance - and that a slab of cake - is one of these dishes which is to feed five persons larger than a student's face.

There is only one thing to be said in favour of this bad book. It is as a good a give-away as one can wish of a vile state of things. Science, medical and domestic, all the jargon and apparatus of a cookery book, coloured plates and pious preface, spell but one word, Malnutrition. Or in plainer English, Not Enough to Eat.

On every other count the book is as about as bad as it can be. The recipes are unpractical and wasteful of time and fuel, both important considerations in a working-class household. Half an hour's cooking, 'stirring all the time', is laid down to produce a brown gravy made from water, flour, an onion and one ounce of dripping. The shopping lists are drawn up with little attention to real conditions. The quarter of a pound of tomatoes is priced at a penny. Greens are a penny a pound, a pound and a half of plums is twopence - interesting calculation for the greengrocer and in the sanguine expectation of the B.M.A., two heads of celery - large enough to supply a dish for five, and sufficient outside leaves to flavour two evening meals of soup - can be bought for threepence. By combing the 
cheapest town markets, vegetables at such prices may be found; but to buy them, as every housekeeper knows, is bad economy, since they will be stale or so badly damaged that a large part of them must needs be discarded before cooking.

Moreover, the menus are monotonous and badly balanced. In the first week's shopping list the starch foods (bread, flour, potatoes, rice) amount to $49 \mathrm{lbs}$., as against $12 \mathrm{lbs}$ (uncooked weight) of fruit and vegetables. The voice of the B.M.A. impresses on us the danger of constipation to the public health, and urges us to eat fresh fruit and fresh vegetables. But their cookery book confesses that such things as vitamins and natural laxatives must be beyond the reach not only of those living on the dole but of a large proportion of workers.

From The Countryman. An Illustrated Review \& Miscellany of Rural Life and Industry. Ed. J.W. Robertson Scott. Vol. XII January 1936, pp.563-567. 
Copyrighted image removed

Handwritten Carnegie ledger entry for Sylvia Townsend Warner.

By kind permission of The National Archives of Scotland 